7 McGonigal G, McQuade C, Thomas B and Whalley LJ. Survival in presenile Alzheimer's and multi-infarct dementias. Neuroepidemiology 1992;11;121-6. 8 Martin GM, Schellenberg GD, Wijsman EM, Bird TD. Dominant susceptibility genes. Nature 1990;347:124.

9 Morris JN. Uses of epidemiology. Edinburgh: Livingstone, 1964

10 World Health Organisation. International Classification of Disease. Ninth edition. Geneva: WHO, 1977

11 Cohen J. A coefficient of agreement for nominal scales. Education and Psychological Measures 1960;20:37-46.

12 McKhann G, Drachman D, Folstein M, Katzman R, Price D, Stadlan EM Clinical diagnosis of Alzheimer's disease; report of the NINCDS-ADRDA work group under the auspices of the Department of Health and Human work group under the auspices of the Department of Health and Hum
Services Task Force on Alzheimer's disease. Neurology 1984;34:939-44.

13 Hachinski VC, Illiff LD, Zalka E, duBoulay GHD, McAlister VL, Marshall J, et al. Cerebral blood flow in dementia. Arch Neurol 1975;32:632-7.

14 McGonigal G, Thomas B, McQuade C, Whalley LJ. Clinical diagnosis of presenile Alzheimer's disease: a novel approach. International fournal of Geriatric Psychiatry 1992;7:751-6.

15 Landis JR, Koch GG. The measurement of observer agreement for categorical data. Biometrics 1977;33:159-74.
16 Kukull WA, Larson EB, Reifler BV, Lampe TH, Yerby M, Hughes J. Interrater reliability of Alzheimer's disease diagnosis. Neurology 1990;40: 257-61.

17 Zhang MY, Katzman R, Salmon D, Jin H, Cai GJ, Wang ZY, et al. The prevalence of dementia and Alzheimer's disease in Shanghai, China: impact of age, gender and education. Ann Neurol 1990;27:428-37.

18 Jorm AF, Korten AE, Henderson AS. The prevalence of dementia: a quantitative integration of the literature. Acta Psychiatr Scand 1987;76: 465-79.

19 Pfeffer RI, Afif AA, Chance JM. Prevalence of Alzheimer's disease in a retirement community. Am $\mathcal{F}$ Epidemiol 1987;125:420-36.

20 Rocca WA, Bonaiuton S, Lippi A, Luciano P, Turtu F, Cavarzeran F, et al. Prevalence of clinically diagnosed Alzheimer's disease and other dementing disorders: a door-to-door survey in Appignano, Macerata Province, Italy. Neurology 1990;40:626-31.

21 Buhl L, Bojsen-Moller M. Frequency of Alzheimer's disease in a postmortem study of psychiatric patients. Dan Med Bull 1988;35:288-90.

(Accepted 31 December 1992)
School of Public Health, University of Leeds, Leeds Fujian Song, research fellow Nick Freemantle, research fellow

Centre for Health

Economics, University of

York, York YO1 5DD

Trevor A Sheldon, senior research fellow

James Mason, research fellow

Department of Liaison

Psychiatry, Leeds General

Infirmary, Leeds

Allan House, consultant

psychiatrist

Academic Unit of Public

Health Medicine,

University of Leeds

Paul Watson, senior registrar

Nuffield Institute for

Health Services Studies,

University of Leeds, Leeds

Andrew Long, senior lecturer

Correspondence to:

Mr Sheldon.

BMF 1993;306:683-7

\title{
Selective serotonin reuptake inhibitors: meta-analysis of efficacy and acceptability
}

\author{
Fujian Song, Nick Freemantle, Trevor A Sheldon, Allan House, Paul Watson, Andrew Long, \\ James Mason
}

Abstract

Objective-To examine the evidence for using selective serotonin reuptake inhibitors instead of tricyclic antidepressants in the first line treatment of depression.

Design-Meta-analysis of 63 randomised controlled trials comparing the efficacy and acceptability of selective serotonin reuptake inhibitors with those of tricyclic and related antidepressants.

Main outcome measures-Improvement in mean scores on Hamilton depression rating scale for $\mathbf{5 3}$ randomised controlled trials. Pooled drop out rates from the 58 trials which reported drop out by treatment group.

Results-Among the 20 studies reporting standard deviation for the Hamilton score no difference was found in efficacy between serotonin reuptake inhibitors and tricyclic and related antidepressants (standardised mean difference $0.004,95 \%$ confidence interval -0.096 to $0 \cdot 105$ ). The difference remained insignificant when the remaining 33 studies that used the 17 item and 21 item Hamilton score were included by ascribing weighted standard deviations. The odds ratio for drop out rate in patients receiving serotonin reuptake inhibitors compared with those receiving tricyclic antidepressants was $0.95(0.86$ to 1.07$)$. Similar proportions in both groups cited lack of efficacy as the reason for dropping out but slightly more patients in the tricyclic group cited side effects $(18.8 \% v 15.4 \%$ in serotonin reuptake group).

Conclusions-Routine use of selective serotonin reuptake inhibitors as the first line treatment of depressive illness may greatly increase cost with only questionable benefit.

\section{Introduction}

Selective serotonin reuptake inhibitors are a relatively new class of antidepressants that have been heavily promoted for use as first line treatment in depression. They are the most commonly prescribed antidepressant in the United States,' but their routine use in Britain is controversial. ${ }^{2-4}$

The high specificity of serotonin reuptake inhibitors, without antagonism of neurotransmitter receptors or direct cardiac effects, has led to the expectation that they have the same antidepressant activity as tricyclic and related antidepressants but do not produce many of the common side effects. ${ }^{5}$ Thus it is claimed that they have two important advantages over tricyclic and related antidepressants - they are better tolerated and are less toxic in overdose. ${ }^{4}$ However, disagreement exists about the role of serotonin reuptake inhibitors in treating major depression. ${ }^{23}$

One reason for these differences of opinion is that the claims made for serotonin reuptake inhibitors are often based on the results of individual trials. ${ }^{2}$ Many of the studies are not large enough to detect or exclude with certainty clinically relevant differences in the effects of serotonin reuptake inhibitors and tricyclic and related drugs. We reviewed the evidence for the efficacy and acceptability of serotonin reuptake inhibitors compared with the tricyclic and related antidepressants by meta-analysis. We included data from all comparable randomised controlled trials, which enables smaller effects to be detected or excluded with confidence. The large number of studies also gives the findings potentially greater generalisability.

\section{Methods}

We conducted a meta-analysis of the results of efficacy studies and of the drop out rates. We identified 64 randomised controlled trials comparing serotonin reuptake inhibitors with tricyclic or related antidepressants by searching Medline and Index Medicus, manual cross referencing, and discussion with experts (table I). ${ }^{0-69}$ One study did not use a double-blind design and was therefore excluded from the analysis." multicentre studies have been published in aggregate and separately, and we took great care to avoid including the same results more than once. ${ }^{70}$

\section{EFFICACY}

The trials used various psychometric instruments to measure the efficacy of treatments. The most consistently used instrument, the Hamilton depression rating scale, ${ }^{71}{ }^{72}$ was included in 61 of the trials. The Hamilton depression rating scale is a reliable instrument that is particularly weighted towards and sensitive to change in somatic symptoms rather than psychological and cognitive factors. ${ }^{73}$ Most studies used either the 17 question or the 21 question instrument, although other versions were occasionally used. However, it is generally accepted that none of the items which supplement 


\begin{tabular}{|c|c|c|c|c|c|c|c|c|c|}
\hline \multirow[b]{2}{*}{ Author (year) } & \multirow[b]{2}{*}{$\begin{array}{l}\text { Serotonin reuptake } \\
\text { inhibitors (mg/day) }\end{array}$} & \multirow[b]{2}{*}{$\begin{array}{c}\text { Tricyclic } \\
\text { antidepressants } \\
\text { (mg/day) }\end{array}$} & \multirow[b]{2}{*}{$\begin{array}{l}\text { No of weeks' } \\
\text { treatment }\end{array}$} & \multicolumn{2}{|c|}{ No of patients } & \multirow[b]{2}{*}{$\begin{array}{l}\text { Difference in } \\
\text { mean Hamilton } \\
\text { score }^{\star}(\mathrm{SE})\end{array}$} & \multicolumn{2}{|c|}{ No of drop outs } & \multirow{2}{*}{$\begin{array}{l}\text { Odds ratio of drop } \\
\text { outs }(95 \% \\
\text { confidence } \\
\text { interval) }\end{array}$} \\
\hline & & & & $\begin{array}{l}\text { Serotonin } \\
\text { reuptake } \\
\text { inhibitors }\end{array}$ & $\begin{array}{c}\text { Tricyclic } \\
\text { antidepressants }\end{array}$ & & $\begin{array}{c}\text { Serotonin } \\
\text { reuptake } \\
\text { inhibitors }\end{array}$ & $\begin{array}{c}\text { Tricyclic } \\
\text { antidepressants }\end{array}$ & \\
\hline Altamura et al ${ }^{\circ}(1989)$ & Fluoxetine (20) & Amitriptyline (75) & 5 & 14 & 14 & $4.00(2.38) \dagger$ & 2 & 4 & $0.42(0.06$ to 2.77$)$ \\
\hline Amore et al ${ }^{\top}(1989)$ & Fluvoxamine $(50-150)$ & Imipramine $(50-150)$ & 4 & 15 & 15 & $1.00(\mathrm{NA}) \neq$ & 0 & 5 & \\
\hline $\begin{array}{l}\text { Bascara }^{8}(1989) \\
\text { Bignamini and }\end{array}$ & Paroxetine (20-30) & Amitriptyline (50-75) & 6 & 27 & 23 & NA & 2 & 3 & $0.53(0.08$ to 3.51$)$ \\
\hline Rapisarda ${ }^{\circ}$ (1992) & Paroxetine (20-30) & Amitriptyline (75-150) & 6 & 156 & 153 & 1.00 (NA)‡ & 31 & 20 & $1.65(0.89$ to 3.04$)$ \\
\hline Bramanti et al ${ }^{10}(1988)$ & Fluvoxamine $(50-150)$ & Imipramine $(50-150)$ & 4 & 30 & 30 & $2.65(1.21) \ddagger$ & 2 & 1 & $2.07(0.18$ to $24 \cdot 15)$ \\
\hline $\operatorname{Bremner}^{12}(1984)$ & Fluoxetine $(20-80)$ & Imipramine (75-300) & 5 & 20 & 20 & NA & 4 & 3 & $1.42(0.27$ to 7.34$)$ \\
\hline Bressa et al ${ }^{13}(1989)$ & Fluoxetine $(20-60)$ & Imipramine $(50-175)$ & 5 & 15 & 15 & 4.00 (NA) $\ddagger$ & 2 & 1 & $2.15(0.17$ to 26.67$)$ \\
\hline Chouinard ${ }^{14}(1985)$ & Fluoxetine $(20-80)$ & Amitriptyline $(75-300)$ & 5 & 25 & 28 & $4.80(\mathrm{NA}) \ddagger$ & 4 & 6 & $0.70(0.17$ to 2.83$)$ \\
\hline Cohn and Wilcox's (1985) & Fluoxetine $(20-80)$ & Imipramine $(100-300)$ & 6 & 54 & 54 & $-1.15(\mathrm{NA}) \ddagger$ & 19 & 34 & $0.32(0.15$ to 0.70$)$ \\
\hline Cohn et al ${ }^{16}(1990)$ & Sertraline $(50-200)$ & Amitriptyline (50-150) & 8 & 161 & 80 & $-0.60(\mathrm{NA}) \dagger$ & 79 & 41 & $0.92(0.54$ to 1.57$)$ \\
\hline Cohn et al ${ }^{17}(1990)$ & Paroxetine $(10-50)$ & Imipramine $(65-275)$ & 6 & NA & NA & $2.00(\mathrm{NA}) \dagger$ & NA & NA & \\
\hline Corne and Hall' ${ }^{18}$ (1989) & Fluoxetine (40) & Dothiepin (75) & 6 & 49 & 51 & $2 \cdot 20(1.36) \dagger$ & 14 & 7 & $2.51(0.92$ to 6.90$)$ \\
\hline Danish University anti- & & & & & & & & & \\
\hline depressant group ${ }^{10}(1990)$ & Paroxetine (30) & Clomipramine (150) & 6 & 62 & 58 & 6.00 (NA)† & 35 & 23 & $1.97(0.95$ to 4.08$)$ \\
\hline Debus $e t$ al ${ }^{20}(1988)$ & Fluoxetine (20-60) & Trazadone $(50-400)$ & 6 & 22 & 21 & $2.00(\mathrm{NA}) \dagger$ & 8 & 10 & $0.63(0.19$ to 2.13$)$ \\
\hline de Jonghe et $a l^{21}$ (1991) & Fluvoxamine $(50-300)$ & Maprotiline (50-150) & 6 & 24 & 24 & $-0 \cdot 10(2 \cdot 16) \dagger$ & 4 & 6 & $0.60(0.15$ to 2.47$)$ \\
\hline de Jonghe et al ${ }^{22}$ (1991) & Fluoxetine $(40-80)$ & Maprotiline (50-150) & 6 & 30 & 35 & $2 \cdot 60(2.03) \dagger$ & 4 & 6 & $1.19(0.49$ to 2.89$)$ \\
\hline De Wild et al ${ }^{23}$ (1983) & Fluvoxamine $(223-300)$ & Clomipramine (109-144) & 6 & 21 & 23 & $1.30(\mathrm{NA}) \mathrm{t}$ & 0 & 0 & \\
\hline Dick and Ferrero $44(1983)$ & Fluvoxamine $(150)$ & Clomipramine (150) & 4 & 17 & 15 & 1.80 (NA) $\delta$ & 4 & 3 & $1.23(0.23$ to 6.67$)$ \\
\hline Dominguez et al ${ }^{25}$ (1985) & Fluvoxamine $(50-300)$ & Imipramine $(50-300)$ & 4 & 35 & 35 & -0.40 (NA)§ & 19 & 16 & $1.41(0.55$ to 3.61$)$ \\
\hline $\operatorname{Dorman}^{20}(1992)$ & Paroxetine (15-30) & Amitriptyline $(30-60)$ & 6 & 29 & 28 & $-4.00(\mathrm{NA}) \dagger$ & 5 & 3 & $1.74(0.37$ to 8.08$)$ \\
\hline Dunbar et al ${ }^{27}(1991)$ & Paroxetine (20-50) & Imipramine $(65-275)$ & 6 & 240 & 240 & $0.00(\mathrm{NA}) \dagger$ & 102 & 127 & $0.66(0.46$ to 0.94$)$ \\
\hline Dunner et al ${ }^{28}(1992)$ & Paroxetine (10-40) & Doxepin $(<200)$ & 6 & 136 & 135 & $-1.00(\mathrm{NA}) \ddagger$ & 45 & 39 & $1.22(0.73$ to 2.04$)$ \\
\hline Fabre et al ${ }^{29}(1991)$ & Fluoxetine (35) & Nortriptyline (87) & 5 & 103 & 102 & 0.00 (NA) $\int$ & 39 & 45 & $0.77(0.44$ to 1.35$)$ \\
\hline Falk et al ${ }^{10}(1989)$ & Fluoxetine $(20-60)$ & Trazodone $(50-400)$ & 6 & 14 & 13 & $-0.07(4.25) \ddagger$ & 3 & 10 & $0.08(0.01$ to 0.50$)$ \\
\hline Feighner et al $l^{31}$ (1991) & Fluoxetine 20-80) & Buprapin (225-450) & 6 & 62 & 61 & $1.40(\mathrm{NA}) \ddagger$ & 18 & 16 & $1.15(0.52$ to 2.54$)$ \\
\hline Feighner et $a l^{12}(1989)$ & Fluvoxamine $(85-280)$ & Imipramine $(50-280)$ & 6 & 31 & 36 & $-5.00(\mathrm{NA}) \ddagger$ & 10 & 9 & $1.43(0.49$ to 4.15$)$ \\
\hline Feighner and Cohn"31 (1985) & Fluoxetine $(20-80)$ & Doxepin $(50-250)$ & 6 & 78 & 79 & $-0.29(\mathrm{NA}) \ddagger$ & 37 & 48 & $0.58(0.31$ to 1.10$)$ \\
\hline Feighner $^{34}(1985)$ & Fluoxetine $(20-80)$ & Amitriptyline $(75-300)$ & 5 & 22 & 22 & $2.00(\mathrm{NA}) \ddagger$ & 5 & 12 & $0.25(0.06$ to 0.90$)$ \\
\hline Ferreri" (1989) & Fluoxetine (20) & Amitriptyline (100) & 6 & 31 & 32 & $-0.30(\mathrm{NA}) \ddagger$ & 4 & 7 & $0.53(0.14$ to 2.03$)$ \\
\hline Ginestete $^{36}$ (1989) & Fluoxetine (58) & Clomipramine (148) & 8 & NA & NA & $0.20(2 \cdot 67) \ddagger$ & NA & NA & \\
\hline Gonella et al ${ }^{37}$ (1990) & Fluvoxamine $(100-150)$ & Imipramine $(100-150)$ & 4 & 10 & 10 & $-1.90(3.92) \ddagger$ & 1 & 0 & \\
\hline Guelfi et $a l^{38}(1987)$ & Fluvoxamine $(100-300)$ & Imipramine $(50-200)$ & 4 & 77 & 81 & $-2.60(1.86) \S$ & 19 & 18 & $1.15(0.55$ to 2.40$)$ \\
\hline Guillibert et $a l^{19}(1989)$ & Paroxetine $(20-30)$ & Clomipramine $(25-75)$ & 6 & 40 & 39 & $0.20(\mathrm{NA}) \ddagger$ & 9 & 12 & $0.65(0.24$ to 1.79$)$ \\
\hline Guy et $\mathrm{al}^{+0}(1984)$ & Fluvoxamine $(150-225)$ & Imipramine (150-225) & 6 & 17 & 19 & $\mathrm{NA}$ & NA & NA & \\
\hline Hutchinson et $\mathrm{ll}^{+1}$ (1992) & Paroxetine (20) & Amitriptyline (100) & 6 & 58 & 32 & 0.00 (NA) $\ddagger$ & 12 & 11 & $0.50(0.19$ to 1.31$)$ \\
\hline Itil et $a l^{42}(1983)$ & Fluvoxamine $(50-210)$ & Imipramine $(50-210)$ & 4 & 22 & 25 & NA & 12 & 12 & $1.30(0.41$ to 4.10$)$ \\
\hline Kuhs and Rudolf' (1989) & Paroxetine (30) & Amitriptyline (150) & 6 & 20 & 20 & $0.40(\mathrm{NA}) \ddagger$ & 6 & 3 & $2.43(0.51$ to 11.51$)$ \\
\hline Laakmann et al ${ }^{+4}(1988)$ & Fluoxetine (20-60) & Amitriptyline $(50-150)$ & 5 & 65 & 65 & $5.00(2.45) \dagger$ & 29 & 22 & $1.57(0.78$ to 3.20$)$ \\
\hline Lapierre et al ${ }^{45}(1987)$ & Fluvoxamine (180) & Imipramine (173) & 6 & 22 & 21 & $-5.00(\mathrm{NA}) \dagger$ & 7 & 12 & $0.35(0.10$ to 1.22$)$ \\
\hline Laursen et al ${ }^{\circ 0}$ (1985) & Paroxetine (30) & Amitriptyline $(50-150)$ & 6 & 21 & 23 & 2.00 (NA) $\dagger$ & 5 & 9 & $0.49(0.13$ to 1.80$)$ \\
\hline Levine et al ${ }^{47}(1987)$ & Fluoxetine $(40-60)$ & Imipramine $(75-150)$ & 6 & 30 & 30 & $3.40(\mathrm{NA}) \ddagger$ & 8 & 2 & $5.09(0.98$ to 26.43$)$ \\
\hline Loeb et $a l^{48}(1989)$ & Fluoxetine (20) & Imipramine $(50-75)$ & 5 & 15 & 15 & $-5.76(\mathrm{NA}) \dagger$ & NA & NA & \\
\hline Manna et $a l^{4 \circ}(1989)$ & Fluoxetine (20) & Clomipramine (75) & 5 & 15 & 15 & $-1.00(1.65) \dagger$ & NA & NA & \\
\hline March et al $l^{50}(1990)$ & Fluvoxamine $(50-300)$ & Imipramine $(50-300)$ & 6 & 18 & 18 & $-2.00(\mathrm{NA}) t$ & 5 & 3 & $1.92(0.38$ to 9.65$)$ \\
\hline Mertens and & & & & & & & & & \\
\hline Pintens "1 (1988) & Paroxetine (30) & Mianserin (60) & 6 & 38 & 32 & $-6.00(\mathrm{NA}) \ddagger$ & 5 & 4 & $1.06(0.26$ to 4.34$)$ \\
\hline Muijen et al ${ }^{52}(1988)$ & Fluoxetine $(40-80)$ & Mianserin (40-80) & 6 & 26 & 27 & $-4 \cdot 00(3 \cdot 38) \dagger$ & 12 & 13 & $0.92(0.31$ to 2.72$)$ \\
\hline Mullin et al $l^{53}$ (1988) & Fluvoxamine $(100-300)$ & Dothiepin (75-225) & 6 & 37 & 36 & $-0.20(\mathrm{NA}) \dagger$ & 11 & 12 & $0.85(0.32$ to 2.27$)$ \\
\hline Nielsen et al ${ }^{44}(1991)$ & Paroxetine $(20-40)$ & Imipramine $(100-200)$ & 12 & 16 & 15 & $-2.00(\mathrm{NA}) \dagger$ & 4 & 1 & $0.52(0.12$ to 2.17$)$ \\
\hline Norton et al ${ }^{59}(1984)$ & Fluvoxamine (133) & Imipramine (153) & 4 & 35 & 31 & $0.30(\mathrm{NA}) \dagger$ & 4 & 1 & $3.87(0.41$ to 36.66$)$ \\
\hline Perez and Ashford ${ }^{50}(1990)$ & Fluvoxamine $(100-600)$ & Mianserin $(60-360)$ & 6 & 30 & 33 & NA & 9 & 9 & $1.14(0.38$ to 3.41$)$ \\
\hline Perry et al $l^{57}(1989)$ & Fluoxetine (20-60) & Trazodone $(50-400)$ & 6 & 21 & 19 & $1.90(2.64) \S$ & 4 & 4 & $0.88(0.19$ to 4.16$)$ \\
\hline Peselow et al ${ }^{88}(1989)$ & Paroxetine (10-50) & Imipramine (65-275) & 6 & 40 & 40 & $8.56(\mathrm{NA}) t$ & 11 & 12 & $0.89(0.34$ to 2.33$)$ \\
\hline Phanjoo et al ${ }^{\circ \circ}(1991)$ & Fluvoxamine $(100-200)$ & Mianserin $(40-80)$ & 6 & 25 & 25 & Did not use & 9 & 10 & $0.84(0.27$ to 2.65$)$ \\
\hline Poelinger and & & & & & & & & & \\
\hline Haber $^{\circ 0}(1989)$ & Fluoxetine (40) & Maprotiline (75) & 4 & 73 & 69 & $-1.00(1.13)$ & 12 & 8 & $1.50(0.57$ to 3.93$)$ \\
\hline Rahman et al ${ }^{\circ 1}$ (1991) & Fluvoxamine $(50-200)$ & Dothiepin $(50-200)$ & 6 & 26 & 26 & Did not use & 9 & 7 & $1.44(0.44$ to 4.70$)$ \\
\hline Reimherr et al ${ }^{12}(1990)$ & Sertraline $(50-200)$ & Amitriptyline $(50-150)$ & 8 & 126 & 122 & $1.72(0.82) t$ & 61 & 63 & $0.95(0.60$ to 1.50$)$ \\
\hline Ropert' (1989) & Fluoxetine (20) & Clomipramine (75) & 5 & 71 & 72 & $-1.40(0.97) \ddagger$ & 16 & 24 & $0.58(0.28$ to 1.22$)$ \\
\hline Roth et al $l^{64}(1990)$ & Fluvoxamine $(100-300)$ & Desipramine $(100-300)$ & 6 & 30 & 30 & $-1.20(2.56) \dagger$ & 6 & 9 & $0.58(0.18$ to 1.91$)$ \\
\hline South Wales Antidepressant & & & & & & & & & \\
\hline Drug Trial Group ${ }^{\circ 5}(1988)$ & Fluoxetine $(40-80)$ & Dothiepin (50-225) & 6 & 31 & 28 & $-0.40(1.72) \dagger$ & 15 & 7 & $2.81(0.93$ to 8.52$)$ \\
\hline Stark and Hardison ${ }^{\circ \circ}$ (1985) & Fluoxetine $(20-80)$ & Imipramine $(100-300)$ & 6 & 185 & 186 & $0.30(1.05) \ddagger$ & 87 & 87 & $1.01(0.67$ to 1.52$)$ \\
\hline Tamminen and & & & & & & & & & \\
\hline Lehtinen $^{67}(1989)$ & Fluoxetine $(40-80)$ & Doxepin $(50-150)$ & 5 & 26 & 25 & $-1.00(\mathrm{NA}) \dagger$ & 5 & 4 & $1.25(0.29$ to 5.31$)$ \\
\hline Taneri and Köhleres (1989) & Fluoxetine (40) & Nomifensine (150) & 5 & 20 & 20 & $-2.50(2.47) \Omega$ & 5 & 1 & $6.33(0.67$ to 60.17$)$ \\
\hline Young et al $l^{\circ}(1987)$ & Fluoxetine $(40-80)$ & Amitriptyline $(50-150)$ & 6 & 32 & 32 & NA & 7 & 7 & $1.00(0.31$ to 3.27$)$ \\
\hline
\end{tabular}

*The difference in mean Hamilton score was calculated from data reported at the last week of the trial: difference in mean score=mean score in serotonin reuptake inhibitor group-mean score in tricyclic group. $\nmid 17$ Item Hamilton scale. $\ddagger 21$ Item Hamilton scale. 0 Other items or unknown items of Hamilton scale. NA=not available.

the basic 17 questions provide additional information of value.

The mean difference in Hamilton scores between patients treated with serotonin reuptake inhibitors and those treated with tricyclic or related antidepressants (treatment difference) was calculated for each trial. A pooled estimate of the treatment difference was calculated by averaging all the treatment differences, weighting each by the inverse of the individual squared standard errors. ${ }^{74}$ This gave larger studies, with tighter confidence intervals, more influence in the pooled estimate of difference in efficacy than smaller ones.

Only 20 trials presented the standard deviation of Hamilton scores needed to calculate the weights. A test for heterogeneity (non-random differences) of standardised treatment difference between the studies, with a $\chi^{2}$ statistic, showed no significant heterogeneity $(Q=23.58, \mathrm{df}=19 ; \mathrm{p}=0.213),{ }^{75}$ so a fixed effects method was used to estimate the pooled difference in efficacy. ${ }^{76}$

To avoid the potential bias from using only 20 trials, we ascribed a standard deviation to the remaining 33 studies which used the 17 or 21 item Hamilton scale. Since the standard deviations of the scores from the 16 trials using the 17 or 21 item scale were similar, for each scale a weighted average of these standard deviations was used to calculate a standard error for each of the 33 studies. Pooled estimates of treatment differences were calculated for all 49 studies and compared with the estimate derived from the 16 studies that presented standard deviations for either the 17 or 21 item Hamilton scale. 
ACCEPTABILITY

Acceptability to patients is an important element in a treatment's effectiveness. ${ }^{77}$ Drop out, which is a useful measure of acceptability, ${ }^{78}$ was reported in 58 trials. We compared drop out rates in the two arms of the trials and analysed the main subjective reasons given by patients for discontinuing therapy (inefficacy and side effects) when available.

The ratio of drop out rate of patients in the serotonin reuptake inhibitor group to that in the tricyclic and related antidepressant group (odds ratio) was calculated for each study. A pooled estimate of the overall odds ratio of drop out was calculated by weighting each odds ratio by the inverse of the variance; thus studies with more subjects were given more weight. The odds ratio was heterogeneous among studies $(Q=78 \cdot 79, \mathrm{df}=57$; $\mathrm{p}=0.03$ ) and so the pooled odds ratio was calculated by a random effects method. ${ }^{75} 79$

\section{Results}

EFFICACY

Of the 20 trials which presented the mean Hamilton score and its standard deviations, six used the 21 item Hamilton scale, 10 the 17 point scale and four other versions. Pooled results are presented separately for the 17 and 21 item version of the scale and then all 20 trials were combined by using the standardised difference between mean Hamilton scores for the serotonin reuptake inhibitor and tricyclic and related antidepressant groups: Standardised difference $=$ difference between means/standard deviation.

The average baseline Hamilton score was about 26 on the 21 item scale and 24 on the 17 item scale. No significant difference was found in mean Hamilton score in the 21 item scale for serotonin reuptake inhibitors compared with tricyclic and related anti-

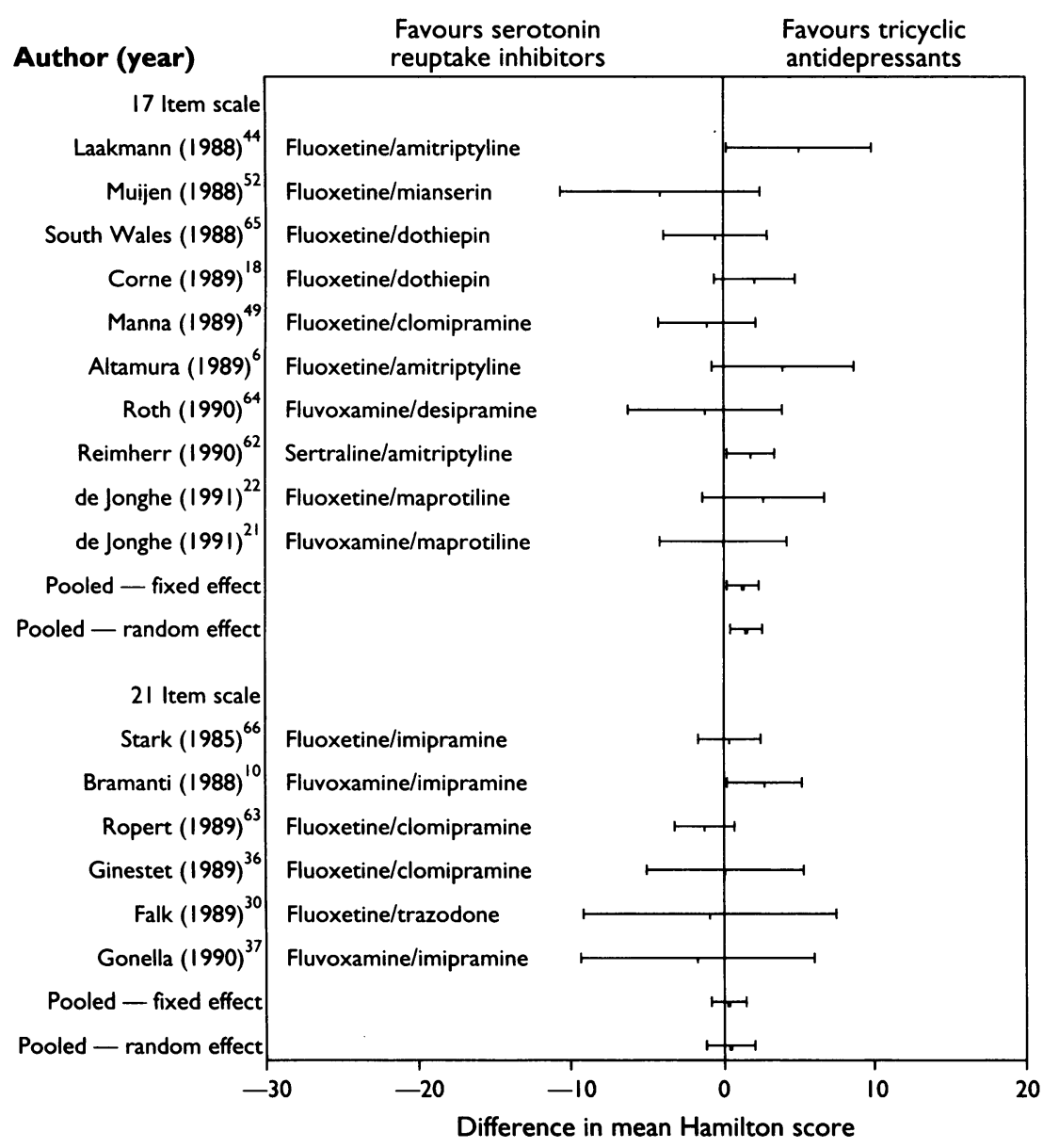

FIG 1-Difference (95\% confidence interval) in mean Hamilton score in patients treated with serotonin reuptake inhibitors or tricyclic and related antidepressants (from data reported at last week of trial)
TABLE II-Drop out rate in patients treated with serotonin reuptake inhibitors and tricyclic and related antidepressants

\begin{tabular}{lcc}
\hline & $\begin{array}{c}\text { No (\%) receiving } \\
\text { serotonin reuptake } \\
\text { inhibitors }\end{array}$ & $\begin{array}{c}\text { No (\%) receiving } \\
\text { tricyclic } \\
\text { antidepressants }\end{array}$ \\
\hline $\begin{array}{l}\text { Total drop outs (58 studies) } \\
\begin{array}{l}\text { Reason for drop out: } \\
\text { Side effects (51 studies) }\end{array}\end{array}$ & $2817(32 \cdot 3)$ & $2701(33 \cdot 2)$ \\
$\begin{array}{l}\text { Inefficacy (39 studies) } \\
\text { (n) }\end{array}$ & $2556(15 \cdot 4)$ & $2445(18 \cdot 8)$ \\
& $2155(7 \cdot 0)$ & $2042(6 \cdot 8)$ \\
\hline
\end{tabular}

TABLE III-Odds ratio of drop out in patients treated with serotonin reuptake inhibitors compared with tricyclic and related antidepressants

\begin{tabular}{lcc}
\hline Drop outs & Odds ratio & 95\% Confidence interval \\
\hline Fluoxetine & 0.921 & 0.699 to 1.215 \\
Fluvoxamine & 1.013 & 0.756 to 1.358 \\
Paroxetine & 0.973 & 0.779 to 1.216 \\
All serotonin reuptake & & 0.816 to $1.107^{\star}$ \\
$\quad$ inhibitors & 0.950 & 0.648 to 1.001 \\
Due to side effects & 0.805 & 0.801 to 1.304 \\
Due to inefficacy & 1.022 & \\
\hline
\end{tabular}

${ }^{\star} Q=78 \cdot 79, \mathrm{df}=57 ; \mathrm{p}=0.0295$.

depressants, after up to eight weeks of treatment (mean difference $0 \cdot 13 ; 95 \%$ confidence interval -1.01 to 1.28) (fig 1). Tricyclic and related antidepressants were significantly more effective than the serotonin reuptake inhibitors in trials using the 17 item scale (mean difference $1 \cdot 29,0 \cdot 28$ to $2 \cdot 30$ ) (fig 1 ) but the difference was not clinically important.

Overall, in the 20 trials which presented the standard deviation of the Hamilton score the tricyclic and related antidepressants showed a small but non-significant benefit in efficacy when compared with the serotonin reuptake inhibitors (standardised difference $0.004,95 \%$ confidence interval -0.096 to 0.105 ).

We ascribed weighted average standard deviations to the remaining 33 studies that used the 17 or 21 item Hamilton score as an end point so that the results for all 49 studies could be pooled. A standard deviation of 8.27 was ascribed to studies using the 21 item scale and 6.81 to those using the 17 item scale. Again, there were no differences in trials using either the 21 item scale (mean difference $0.147 ;-0.597$ to 0.891 ) or the 17 item scale $(0.727,0.083$ to 1.370$)$. This strengthens the inference that there is no significant difference in efficacy between serotonin reuptake inhibitors and tricyclic and related drugs.

\section{ACCEPTABILITY TO PATIENTS}

Fifty eight studies reported drop out rates during the treatment phase. The pooled drop out rate was $32 \cdot 3 \%$ in patients receiving serotonin reuptake inhibitors and $33 \cdot 2 \%$ among those receiving tricyclic and related antidepressants (table II). The odds ratio for drop out for serotonin reuptake inhibitors compared with tricyclic and related antidepressants was estimated to be 0.95 , which was not significantly different from $1(95 \%$ confidence interval 0.816 to $1 \cdot 107$ ) (table III, fig 2 ).

Several trials reported the reason given by patients for dropping out from treatment. The two most commonly cited reasons were lack of efficacy and side effects. There was no difference in the drop out rate attributed to lack of efficacy among the two groups but drop out because of side effects was slightly more common among patients taking tricyclic antidepressants (tables II and III).

\section{Discussion}

The results of this analysis are particularly important because the populations in the trials were generally similar to that found in primary or ambulatory care, where most first line treatment is undertaken. Our most important finding was that there was no statistically or clinically significant difference in the accept- 
ability of serotonin reuptake inhibitors and tricyclic and related antidepressants in patients with major depression.

The serotonin reuptake inhibitors seem to have similar efficacy to the tricyclic and related antidepressants, but the analysis of efficacy is less reliable than that of acceptability because intention to treat analyses were not widely used, different Hamilton scales were

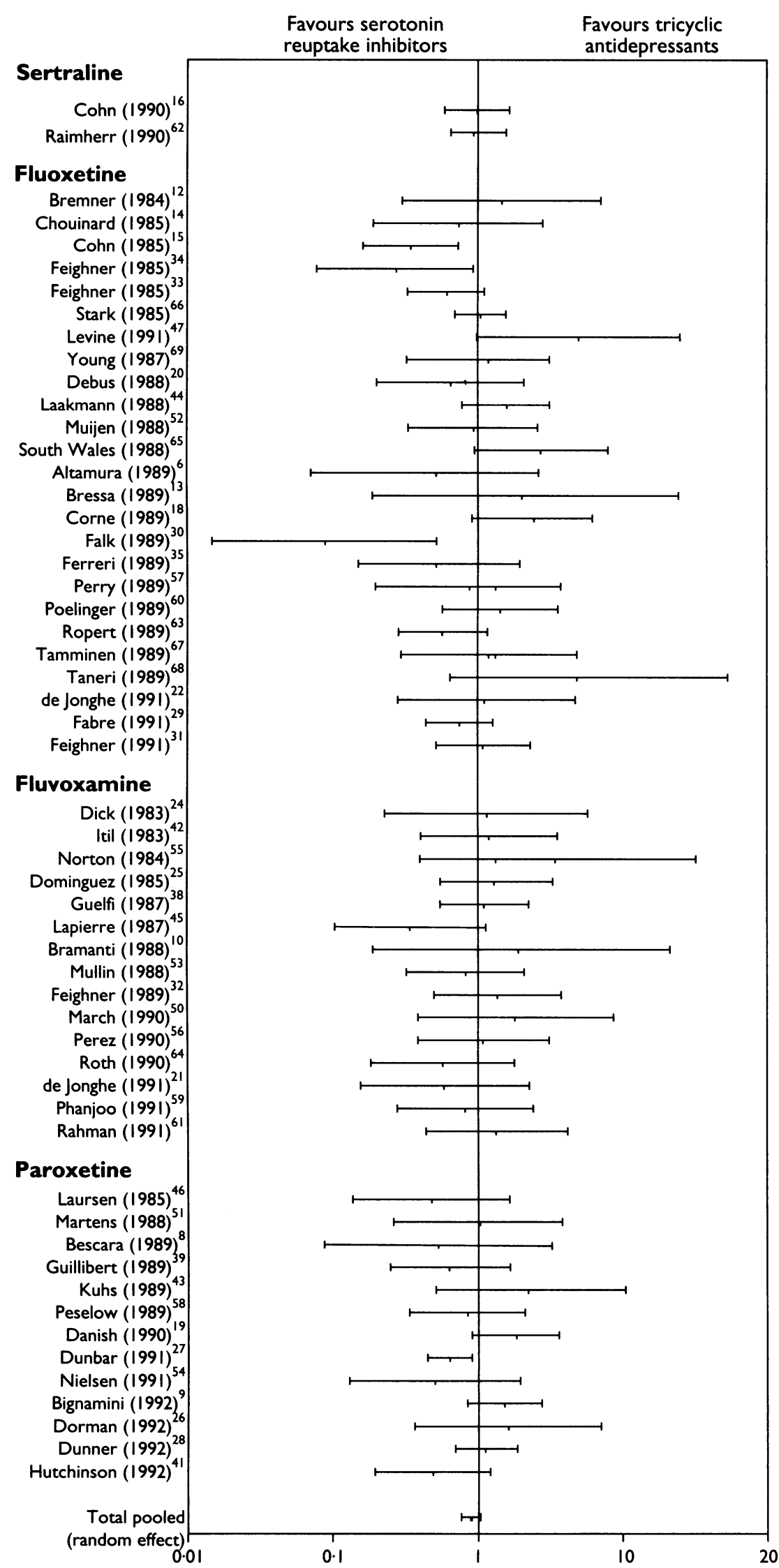

FIG 2-Odds ratio of drop out in patients treated with selective serotonin reuptake inhibitors and tricyclic and related antidepressants used, and reporting of standard deviation was inadequate. The length of follow up in all the studies (median six weeks) was short relative to the generally accepted desirable duration of treatment in this population. ${ }^{80}$

In addition the study populations were heterogeneous despite all meeting the criteria for major depression. Some patients had a short lived mood disorder, which would be likely to resolve rapidly, perhaps without treatment. Others had a more persistent disorder, some of whom had already been treated unsuccessfully. Spontaneous resolution is likely to reduce the ability of any trial to show differences in the effect of treatment. On the other hand, the fact that some patients had already failed to respond to tricyclics before entering the trial might have introduced a bias against this class of drugs.

Better designed studies with more complete reporting of data would enable more reliable estimates of efficacy of treatment. This is essential for the translation of research findings into clinical practice and should be mandatory in reports in clinical journals.

The lack of evidence of greater efficacy and acceptability of serotonin reuptake inhibitors means that their adoption as the drugs of choice in major depression may be premature, although they may have a role in subgroups of patients in whom other treatments are contraindicated or have failed.

The other argument for prescribing serotonin reuptake inhibitors has been their reported lower toxicity in overdose compared with some antidepressants. However, more knowledge of the long term effects of these drugs is needed before they can be recommended as a safe alternative to tricyclic antidepressants, which are less expensive, equally effective, and well tolerated. It may be more effective to adopt alternative strategies for improving mental health and reducing suicides, as outlined in the recommendations of the Defeat Depression campaign of the Royal Colleges of Psychiatrists and General Practitioners. ${ }^{80}$

In conclusion, our meta-analysis of randomised controlled trials indicates that selective serotonin reuptake inhibitors have no significant advantage in efficacy or acceptability over tricyclic and related antidepressants. This is at odds with some of the claims made in the promotion of serotonin reuptake inhibitors and does not support their increasing use as routine first line treatment for major depression.

1 Sertraline for treatment of depression. Medical Letter on Drugs and Therapeutics 1992;34:47-8

2 Edwards JG. Selective serotonin reuptake inhibitors. BMF 1992;304:1644-6.

3 Fradd SO. Selective serotonin reuptake inhibitors. BMF 1992;305:366.

4 British Association for Psychopharmacology. Guidelines for treating depressive illness with antidepressants. London: British Association for Psychopharmacollness with andide 1992 .

5 Schmidt MJ, Fuller RW, Wong DT. Fluoxetine, a highly selective serotonin reuptake inhibitor: a review of preclinical studies. Br f Psychiatry 1988; 153(suppl 3):40-6.

6 Altamura AC, De Novellis F, Guercetti G, Invernizzi G, Percudani M, Mongomery SA. Fluoxetine compared with amitriptyline in elderly depression: a controlled clinical trial. Int f Clin Pharm Res 1989;9:391-6.

7 Amore M, Bellini M, Berardi D, Berlinazni G, Cervino A, Cremonini G, et al. Double-blind comparison of fluvoxamine and imipramine in depressed patients. Current Therapeutic Research 1989;46:815-20.

8 Bascara L. A double-blind study to compare the effectiveness and tolerability of paroxetine and amitriptyline in depressed patients. Acta Psychiatr Scand 1989;80(suppl 350):141-2.

9 Bignamini A, Rapisarda V. A double-blind multicentre study of paroxetine and amitriptyline in depressed outpatients. Int Clin Psychopharm 1992; 6(suppl 4):37-41.

10 Bramanti P, Ricci RM, Roncari R, Bilone F, Inga F, Teti V, et al. An Italian multicenter experience with fluvoxamine, a new antidepressant drug, versus imipramine. Current Therapeutic Research 1988;43:718-24.

11 Brasseur R. A multicentre open trial of fluoxetine in depressed outpatients in Belgium. Int Clin Psychopharmacol 1989;4(suppl 1):107-11.

12 Bremner JD. Fluoxetine in depressed patients: a comparison with imipramine. J Clin Psychiatry 1984;45:414-9.

13 Bressa GM, Brugnoli R, Pancheri P. A double-blind study of fluoxetine and imipramine in major depression. Int Clin Psychopharmacol 1989;4(suppl 1):69-73

14 Chouinard G. A double-blind controlled clinical trial of fluoxetine and amitriptyline in the treatment of outpatients with major depressive disorder. Clin Psychiatry 1985;46:32-7.

15 Cohn JB, Wilcox C. A comparison of fluoxetine, imipramine, and placebo in patients with major depressive disorder. f Clin Psychiatry 1985;46:26-31. 
16 Cohn CK, Shrivastava R, Mendels J, Cohn JB, Fabre LF, Claghron JI, et al. Double-blind, multicenter comparison of sertraline and amitriptyline in elderly depressed patients. 9 Clin Psychiatry 1990;51(suppl B):28-33.

17 Cohn JB, Crowder JE, Wilcox CS, Ryan PJ. A placebo- and imipraminecontrolled study of paroxetine. Psychopharmacol Bull 1990;26:185-9.

18 Come SJ, Hall JR. A double-blind comparative study of fluoxetine and dothiepin in the treatment of depression in general practice. Int Clin Psychopharmacology 1989;4:245-54.

19 Danish University Antidepressant Group. Paroxetine: a selective serotonin reuptake inhibitor showing better tolerance, but weaker antidepressant effect than clomipramine in a controlled multicenter study. I Affective Disords 1990;18:289-99.

20 Debus JR, Rush AJ, Himmel C, Tyler D, Polatin P, Weissenburger J. Fluoxetine versus trazodone in the treatment of outpatients with major depression. J Clin Psychiatry 1988;49:422-6.

21 De Jonghe F, Swinkels J, Tuynman-Qua H. Randomized double-blind study of fluvoxamine and maprotiline in treatment of depression. Pharmacopsychiatry 1991:24:21-7.

22 De Jonghe F, Ravelli DP, Tuynman-Qua H. A randomized, double-blind study of fluoxetine and maprotiline in the treatment of major depression. Pharmacopsychiatry $1991 ; 24: 62-7$.

23 De Wild JE, Mertens C, Wakelin JS. Clinical trials of fluvoxamine vs chlomipramine with single and three times daily dosing. $\mathrm{Br} f$ Clin Pharmacol 1983;15(suppl 3):427-31S

24 Dick P, Ferrero E. A double-blind comparative study of the clinical efficacy of fluvoxamine and chlomipramine. Brf Clin Pharmacol 1983;15:419-25S.

25 Dominguez RA, Goldstein BJ, Jacobson AF, Steinbook RM. A double-blind placebo-controlled study of fluvoxamine and imipramine in depression. IClin Psychiatry 1985;46:84-7.

26 Dorman T. Sleep and paroxetine: a comparison with mianserin in elderly (Int Psychopharmacol 1992;6(suppl 4):53-8.

27 Dunbar GC, Cohn JB, Fabre LF, Feighner JP, Fieve RR, Mendels J, et al. A comparison of paroxetine, imipramine and placebo in depressed outpatients. Br 7 Psychiatry 1991;159:394-8.

28 Dunner DL, Cohn JB, Walshe T, Cohn CK, Feighner JP, Fieve RR, et al. Two combined, multicenter double-blind studies of paroxetine and doxepin in geriatric patients with major depression. $f$ Clin Psychiatry 1992;53(suppl 2):57-60

29 Fabre LF, Scharf MB, Itil TM. Comparative efficacy and safety of nortriptyline and fluoxetine in the treatment of major depression: a clinical study. $f$ Clin Psychiatry 1991;52(suppl 6):62-7.

30 Falk WE, Rosenbaum JF, Otto MW, Zusky PM, Weilburg JB, Nixon RA. Fluoxetine versus trazodone in depressed geriatric patients. $f$ Geriatr Psychiatry Neurol 1989;2:208-14.

31 Feighner JP, Gardner EA, Johnston JA, Batey SR, Khayrallah MA, Ascher $\mathrm{JA}$, et al. Double-blind comparison of bupropion and fluoxetine in depressed outpatients. $\mathcal{F}$ Clin Psychiatry 1991;52:329-35.

32 Feighner JP, Boyer WF, Meredith $\mathrm{CH}$, Hendrickson GG. A placebocontrolled inpatient comparison of fluvoxamine maleate and imipramine in major depression. Int Clin Psychopharmacol 1989;4:239-44.

33 Feighner JP, Cohn JB. Double-blind comparative trials of fluoxetine and doxepin in geriatric patients with major depressive disorder. $f$ Clin Psychiatry 1985

34 Feighner JP. A comparative trial of fluoxetine and amitriptyline in patients with major depressive disorder. $f$ Clin Psychiatry 1985;46:369-72.

35 Ferreri M. Fluoxetine versus amineptine in the treatment of outpatients with major depressive disorders. Int Clin Psychopharmacol 1989;4(suppl 1): 97-101.

36 Ginestete D. Fluoxetine in endogenous depression and melancholia versus clomipramine. Int Clin Psychopharmacol 1989;4(suppl 1):37-40.

37 Gonella G, Baignoli G, Ecari U. Fluvoxamine and imipramine in the treatment of depressive patients: a double-blind controlled study. Curr Med Res Opin 1990;12:177-84.

38 Guelfi JD, Dreyfus JF, Pichot $P$, and the GEPECEP. A double-blind controlled clinical trial comparing fluvoxamine with imipramine. $\mathrm{Br} f \mathrm{Clin}$ Pharmacol 1983;15(suppl 3):411-7S.

39 Guillibert E, Pelicier Y, Archambaul JC, Chabannes JP, Clerc G, Desvilles M, et al. A double-blind, multicentre study of paroxetine versus clomipramine in depressed elderly patients. Acta Psychiatr Scand 1989;80(suppl 350): $132-4$

40 Guy W, Wilson WH, Ban TA, King DL, Manov G, Fjetland OK. A doubleblind clinical trial of fluvoxamine and imipramine in patients with primary depression. Psychopharmacol Bull 1984;20:73-8.

41 Hutchinson DR, Tong S, Moon CA, Vince M, Clarke A. Paroxetine in the treatment of elderly depressed patients in general practice: a double-blind comparison with amitriptyline. Int Clin Psychopharmacol 1992;6(suppl 4): 43-51.

42 Itil TM, Shrivastava RK, Mukheriee S, Coleman BS, Michael ST. A doubleblind placebo-controlled study of fluvoxamine and imipramine in outpatients with primary depression. Br f Clin Pharmacol 1983;15(suppl
(n) 3):433-8S.

43 Kuhs $\mathrm{H}$, Rudolf GAE. A double-blind study of the comparative antidepressant effect of paroxetine and amitriptyline. Acta Psychiatr Scand 1989;80(suppl 350): $145-6$

44 Laakmann G, Blaschke D, Engel R, Schwarz A. Fluoxetine vs amitriptyline in the treatment of depressed out-patients. Br $\mathcal{F}$ Psychiatry 1988;153(suppl 3):64-8.

45 Lapierre YD, Browne M, Hom E, Oyewumi LK, Sarantidis D, Roberts N, et al. Treatment of major effective disorder with fluvoxamine. 3 Clin Psychiatry 1987;48:65-8.

46 Laursen AL, Mikkelsen PL, Rasmussen S, le Fèvre Honoré P. Paroxetine in the treatment of depression-a randomized comparison with amitriptyline. Acta Psychiatr Scand 1985;71:249-55.

47 Levine S, Deo R, Mahardevan K. A comparative trial of a new antidepressant, fluoxetine. Br f Psychiatry 1987;150:653-5.
48 Loeb C, Albano C, Gandolfo C. Fluoxetine versus imipramine. Int Clin Psychopharmacol 1989;4(suppl 1):75-9.

49 Manna V, Martucci N, Agnoli A. Double-blind controlled study on the clinical efficacy and safety of fluoxetine vs clomipramine in the treatment of major depressive disorders. Int Clin Psychopharmacol 1989;4(suppl 1):81-8.

50 March JS, Kobak KA, Jefferson JW, Mazza J, Greist JH. A double-blind, placebo-controlled trial of fluvoxamine versus imipramine in outpatients with major depression. F Clin Psychiatry 1990;51:200-2.

51 Mertens C, Pintens H. Paroxetine in the treatment of depression. A double blind multicentre study versus mianserin. Acta Psychiatr Scand 1988;77: 683-8.

52 Muijen M, Roy D, Silverstone T, Mehmet A, Christie M. A comparative clinical trial of fluoxetine, mianserin and placebo in depressed outpatients. Acta Psychiatr Scand 1988;78:384-90.

53 Mullin JM, Pandita-Gunawardena VR, Whitehead AM. A double-blind comparison of fluvoxamine and dothiepin in the treatment of major affective disorder. Br I Clin Pract 1988:42:51-5.

54 Nielsen OA, Morsing I, Petersen JS, Larsen T, Moller SE, Manniche PM, et al. Paroxetine and imipramine treatment of depressive patients in a controlled multicentre study with plasma amino acid measurements. Acta Psychiatr Scand 1991;84:233-41.

55 Norton KRW, Sireling LI, Bhat AV, Rao B, Paykel ES. A double-blind comparison of fluvoxamine, imipramine and placebo in depressed patients. Affective Disord 1984;7:297-308.

56 Perez A, Ashford J. A double-blind, randomized comparison of fluvoxamine with mianserin in depressive illness. Curr Med Res Opin 1990;12:234-41.

57 Perry PJ, Garvey MJ, Kelly MW, Cook BL, Dunner FJ, Winokur G. A comparative trial of fluoxetine versus trazodone in outpatients with major depression. F Clin Psychiatry 1989;50:290-4.

58 Peselow ED, Filippi AM, Goodnick P, Barouche F, Fieve RR. The short- and long-term efficacy of paroxetine HCL: A. data from a 6-week double-blind parallel design trial vs. imipramine and placebo. Psychopharmacol Bull parallel design

59 Phanjoo A, Wonnacott S, Hodgson A. Double-blind comparative multicentre study of fluvoxamine and mianserin in the treatment of major depressive episode in elderly people. Acta Psychiatr Scand 1991;83:476-9.

60 Poelinger W, Haber H. Fluoxetine $40 \mathrm{mg}$ vs maprotiline $75 \mathrm{mg}$ in the treatment of out-patients with depressive disorders. Int Clin Psychopharmacol 1989;4(suppl 1):47-50.

61 Rahman MK, Akhtar MJ, Savla NC, Sharma RR, Kellett JM, Ashford JJ. A double-blind, randomised comparison of fluvoxamine with dothiepin in the treatment of depression in elderly patients. Br f Clin Pract 1991;45:255-8.

62 Reimherr FW, Chouinard G, Cohn CK, Cole JO, Itil TM, Lapierre YD, et al. Antidepressant efficacy of sertraline: a double-blind, placebo- and amitriptyline-controlled, multicenter comparison study in outpatients with major depression. F Clin Psychiatry 1990;51(suppl B): 18-27.

63 Ropert R. Fluoxetine versus clomipramine in major depressive disorders. Int Clin Psychopharmacol 1989;4(suppl 1):89-95.

64 Roth D, Mattes J, Sheehan KH, Sheehan DV. A double-blind comparison of fluvoxamine, desipramine and placebo in outpatients with depression. Prog Neuropsychopharmacol Biol Psychiatry 1990;14:929-39.

65 South Wales Antidepressant Drug Trial Group. A double-blind multi-centre trial of fluoxetine and dothiepin in major depressive illness. Int Clin Psychopharmacol 1988;3:75-81.

66 Stark $P$, Hardison D. A review of multicenter controlled studies of fluoxetine vs imipramine and placebo in outpatients with major depressive disorder. f Clin Psychiatry 1985;46:53-8.

67 Tamminen TTA, Lehtinen VV. A double-blind parallel study to compare fluoxetine with doxepin in the treatment of major depressive disorders. Int Clin Psychopharmacol 1989;4(suppl 1):51-6.

68 Taneri Z, Köhler R. Fluoxetine versus nomifensine in outpatients with neurotic or reactive depressive disorder. Int Clin Psychopharmacol 1989;4 (suppl 1):57-61.

69 Young JPR, Coleman A, Lader MH. A controlled comparison of fluoxetine and amitriptyline in depressed out-patients. $\operatorname{Br} \mathcal{F}$ Psychiatry 1987;151: $337-40$

70 Leizorovicz A, Haugh MC, Boissel JP. Meta-analysis and multiple publication of clinical reports. Lancet 1992;340:1 102-3.

71 Hamilton M. A rating scale for depression. $f$ Neurol, Neurosurg Psychiatry 1960;23:56-62.

2 Hamilton $\mathrm{M}$. Development of a rating scale for primary depressive illness. $\mathrm{Br} f$ Soc Clin Psychol 1967;6:278-96.

73 Mann A, Murray R. Measurement in psychiatry. In: Hill P, Murray R, Thorley A, eds. Essentials in postgraduate medicine. 2nd ed. London: Academic Press, 1987

74 Cochran WG. The combination of estimates from different experiments. Biometrics 1954;10:101-29.

75 Der Simonian R, Laird N. Meta-analysis in clinical trials. Controlled Clin Trials 1986;7:177-88.

76 Peto R. Why do we need systematic overviews of randomised trials? Stat Med 1987;6:223-40.

77 Long AF, Sheldon TA. Enhancing effective and acceptable purchaser and provider decisions: overview and methods. Quality in Health Care 1992;1: 74-6.

78 Lader $M$. Fluoxetine efficacy vs comparative drugs: an overview. $\mathrm{Br} F$ Psychiatry 1988;153(suppl 3):51-8.

79 Berlin JA, Laird NM, Sacks HS, Chalmers TC. A comparison of statistical methods for combining event rates from clinical trails. Stat Med 1989;8: 141-51.

80 Paykel ES, Priest RG. Recognition and management of depression in general practice: consensus statement. BMF 1992;305:1198-202.

(Accepted 23 February 1993) 